\title{
Pelatihan Penerapan Magnetic Generator Sebagai Sumber Energi Alternatif Bagi Masyarakat Kelurahan Giritontro, Kabupaten Wonogiri
}

\section{The Training of Magnetic Generator Application as The Alternative Sources of Electrical Energy for The People in Giritontro, Wonogiri}

\author{
Sumarna, Juli Astono, Agus Purwanto, Nur Kadarisman, Dyah Kurniawati Agustika*
}

Jurusan Pendidikan Fisika, FMIPA, UNY, *Email:dyah_kurniawati@uny.ac.id

\begin{abstract}
Abstrak
Terbatasnya energi sumber daya mineral mempengaruhi ketersediaan listrik di berbagai pelosok Indonesia. Untuk mengatasi permasalahan ini, kelompok Pengabdian Kepada Masyarakat (PPM) kami membuat program pelatihan sumber energi listrik alternatif bagi masyarakat di daerah Kelurahan Girotontro, Kabupaten Wonogiri. Sumber energi listrik alternatif yang dibuat menggunakan akumulator sebagai penyedia daya d.c terhubung ke inverter sebagai pengubah transmisi d.c. ke a.c sehingga dapat menyalakan lampu. Masyarakat sangat antusias dalam mengikuti pelatihan dan juga dalam mencoba membuat sumber energi listrik alternatif karena dapat menjawab permasalahan listrik yang ada di daerah mereka.
\end{abstract}

Kata Kunci: sumber energi listrik alternatif, akumulator, inverter

\begin{abstract}
The limited energy mineral resources affect the availability of electricity in various parts of Indonesia. To overcome this problem, our group of Community Service create training a program of alternative sources of electrical energy for the people in the area of Girotontro, Wonogiri. The alternative electrical energy source was created by using the accumulator as the D.C. power supply that was connected to the inverter to convert the d.c. transmission to a.c so that it can turn on the lights. The community was very enthusiastic in training and also in trying to create an alternative source of electrical energy because the training can answer the electricity problems that exist in their area.
\end{abstract}

Keywords: alternative sources of electrical energy, accumulator, inverter

\section{PENDAHULUAN}

Pengembangan teknologi dan pemanfaatan energi alternatif masih sangat jarang dilakukan di Indonesia. Hal ini terlihat dari data Statistik Ketenagalistrikan bahwa jenis energi terbarukan yang terlaporkan masih mengandalkan teknologi pembangkit listrik tenaga mini/mikrohidro, angin, geothermal, dan biomassa (Kementerian ESDM, 2014).

Dari hasil pengamatan di pemukiman warga di Kel. di Kel. Giritontro, Kec. Giritontro, Kab. Wonogiri, ditemukan bahwa masyarakat sering mengalami pemadaman listrik tanpa pemberitahuan, terutama pada musim hujan. Selain itu, masih terdapat beberapa rumah tangga yang masih belum teraliri listrik. Oleh karena itu dengan adanya kegiatan PPM ini diharapkan warga dapat secara mandiri menerapkan sumber energi terbarukan sebagai sumber energi listrik di rumahnya masing-masing dan minimal digunakan untuk penerangan rumah. Sumber listrik alternatif yang digunakan adalah akumulator yang dihubungkan dengan inverter kemudian dihubungkan dengan lampu.

Ada dua jenis bentuk transmisi listrik yaitu arus searah /direct current (d.c) 
dan arus bolak-balik/alternating current (a.c). Pada transmisi d.c tegangan konstan yang tetap menghasilkan arus yang tetap pula. Baterai dan akumulator merupakan sumber transmisi d.c. Namun, transmisi d.c berupa tegangan rendah sehingga tidak dapat mentransmisikan daya pada jarak jauh.

Untuk sumber a.c berdasarkan persamaan

$$
\mathrm{P}=\mathrm{VI}=\mathrm{I} 2 \mathrm{R}
$$

diketahui bahwa ketika tegangan meningkat, arus juga meningkat maka daya akan menurun secara eksponensial oleh karenanya tegangan tinggi dapat mereduksi susut daya. Oleh karenanya listrik yang berasal dari pembangkit listrik dan disalurkan ke rumah-rumah merupakan jenis transmisi a.c. Arus a.c. berosilasi diantara nilai dua tegangan dengan frekuensi tertentu dan arus serta tegangannya yang berubahubah memudahkan untuk menaikkan atau menurunkan tegangan.

Transmisi listrik untuk menyuplai kebutuhan rumah tangga yang digunakan adalah transmisi a.c. Namun karena banyaknya gangguan pada transmisi listrik a.c seperti sering terjadinya pemadaman listrik dan belum tersebar meratanya listrik di seluruh Indonesia maka diperlukan konverter d.c ke a.c.
Inverter daya merupakan piranti yang dapat mengonversi energi listrik dari bentuk d.c dan ke bentuk a.c. Sumber tegangan input inverter dapat menggunakan baterai maupun akumulator (Doucet, et al., 2007 ).

Akumulator merupakan salah satu sumber tegangan DC. Energi listrik yang dikeluarkan oleh akumulator dapat diketahui dari persamaan

$$
\mathrm{W}=\mathrm{VIt}
$$

dengan $\mathrm{W}=$ Energi Listrik (joule), $\mathrm{V}=$ Beda Potensial (volt), I = Kuat Arus Listrik (ampere) (Bishop, 2008).

Kapasitas akumulator biasa dinyatakan dalam jumlah ampere jam $(\mathrm{Ah}=$ kuat arus(Ampere) x waktu(hour)), Akumulator termasuk elemen sekunder karena akumulator yang telah kosong dapat diisi kembali. Dengan demikian terdapat dua proses yaitu, proses pemakaian dan pengisian akumulator. Pengisian arus dialirkan berlawanan dengan waktu pengeluaran isi yang berarti juga bahwa beban aktif dan elektrolit diubah supaya energi kimia akumulator mencapai maksimum (Sullivan, 2001). Skema rangkaian penggunaan inverter dengan sumber masukan berupa akumulator dapat dilihat pada Gambar 1.

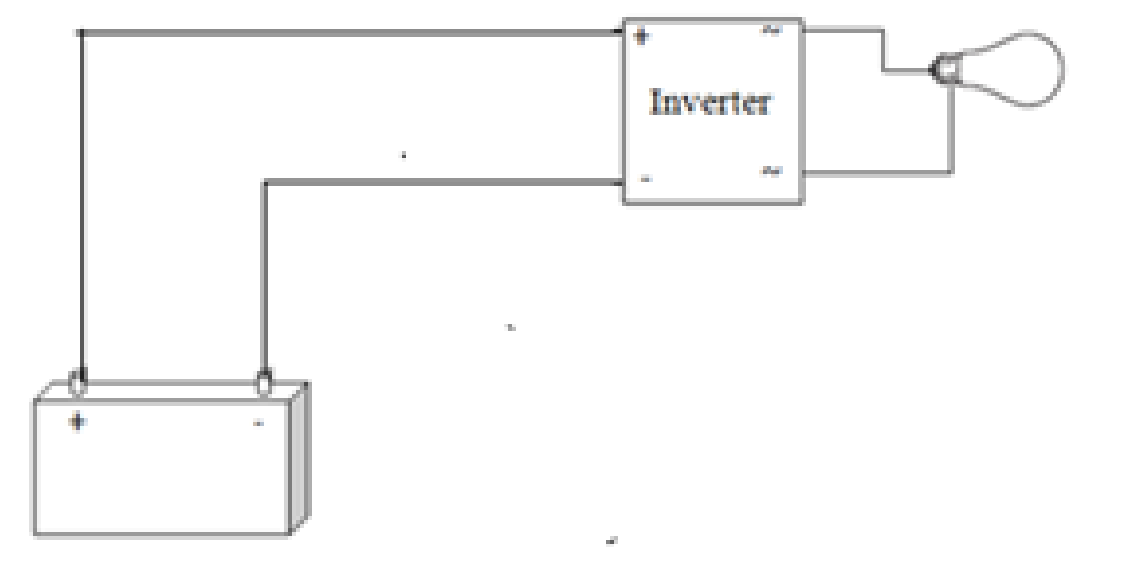

Gambar 1. Skema rangkaian sumber energi listrik alternative 


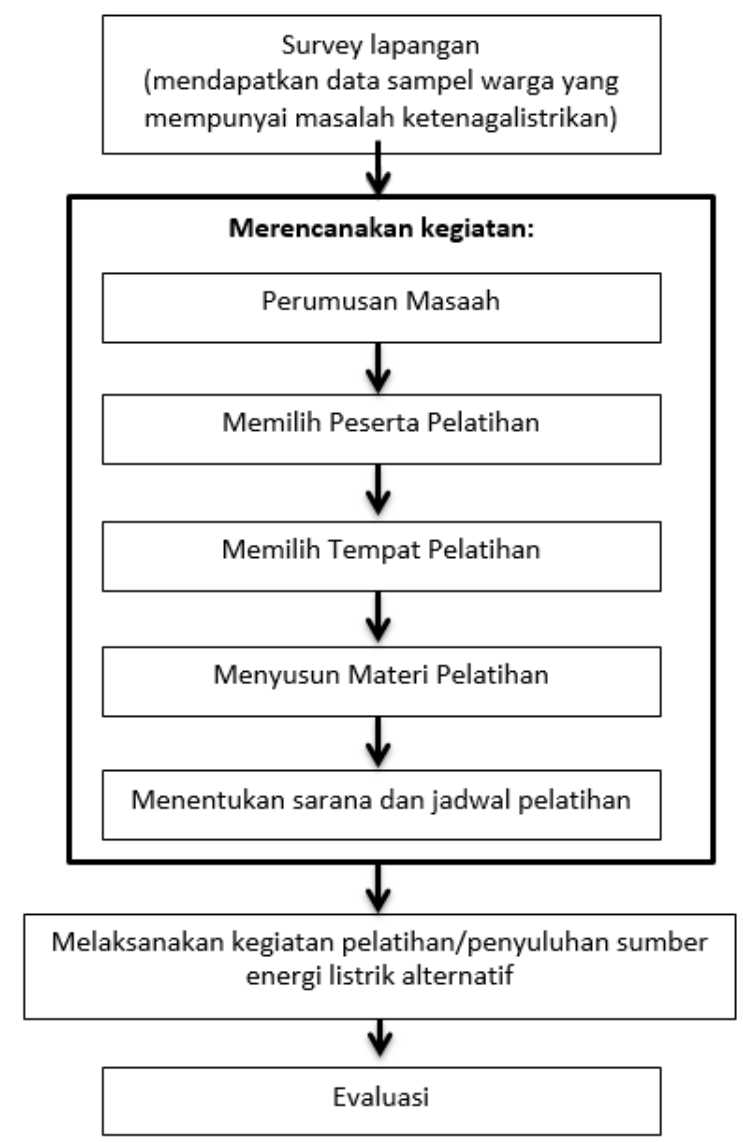

Gambar 2. Diagram alir metode kegiatan PPM

\section{SOLUSI/TEKNOLOGI}

Kegiatan ini diikuti oleh warga Kelurahan Giritontro,Wonogiri dengan melibatkan tokoh desa dan ibu rumah tangga di 2 (dua) RT. Kegiatan penyuluhan dan praktek pembuatan sumber energi listrik alternatif ini melibatkan 30 orang warga.

Metode kegiatan diperlihatkan pada diagram alir di Gambar 2.

\section{HASIL DAN DISKUSI}

Penyuluhan penggunaan sumber energi listrik alternatif dilakukan dengan menggunakan media LCD Projector dan dengan metode ceramah dan tanya jawab. Materi penyuluhan diantaranya menjelaskan tentang: (1) Bahan-bahan yang dapat digunakan sebagai sumber energi altenatif; (2) Pengetahuan umum tentang akumulator dan inverter; (3) Tata cara merangkaian sumber energi alternatif. Setelah ceramah penyuluhan selesai, dilakukan sesi tanya jawab. Kegiatan Tanya jawab yang dilakukan meliputi:

(1) Biaya yang harus dikeluarkan untuk membuat sumber energi listrik alternatif; (2) Berapa lama sumber energi alternatif dapat menyala; (3) Berapa jumlah lampu yang dapat dinyalakan dengan menggunakan akumulator terhubung inverter.

Dari kegiatan penyuluhan dan tanya jawab tersebut, masyarakat diharap dapat termotivasi untuk membuat sumber energi listrik alternatif sendiri. Dari interaksi langsung dengan masyarakat tersebut tim pelaksana juga memperoleh pengetahuan tentang kondisi kelistrikan di daerah Wonogiri. Diakhir acara ada pemberian perangkat sumber energi alternatif kepada warga/

Bedasarkan data kehadiran, pengamatan langsung dan wawancara ke peserta, maka kegiatan pelatihan sumber energi lsitrik alternatif untuk mengangani masalah kelistrikan di kelurahan giritontro, 
kabupaten wonogiri dapat dievaluasi sebagai berikut:

1. Antusiasme masyarakat terhadap kegiatan ini cukup tinggi. Hal ini dapat dilihat dari jumlah masyarakat yang hadir pada kegiatan ini yaitu 24 orang dari total 30 undangan (80\% kehadiran)

2. Dalam hal pemberian materi kepada masyarakat, masyarakat rata-rata sudah paham apa yang disampaikan pemateri. Selain itu partisipasi masyarakat cukup tinggi dalam mengikuti penyuluhan. Hal ini dilihat dari jumlah penanya (3 orang) dan perihal yang ditanyakan.

\section{KESIMPULAN}

Pada kegiatan PPM in, masyarakat yang hadir telah paham mengenai pentingnya mencari sumber energi listrik alternatif dan mereka dapat membuat merangkai akumulator inverter dan lampu dengan benar

Sebagai saran untuk kegiatan ini, masyarakat menyarankan untuk membuat sumber energi listrik alternatif yang lebih murah.

\section{UCAPAN TERIMA KASIH}

Ucapan terima kasih kami haturkan kepada Dekan FMIPA UNY yang telah memberi dana kegiatan PkM. Dan kami ucapkan terimakasih Kepada Masyarakat Kelurahan Giritontro, Kabupaten Wonogiri yang telah mengikuti program PkM ini

\section{PUSTAKA}

Kementrian ESDM. (2014). Statistik Ketenagalistrikan 2014. Jakarta: Direktorat Jendral

Ketenagalistrikan-Kementrian Energi dan Sumber Daya Mineral.

Doucet J., Eggleston D., Shaw J., DC/AC Pure Sine Wave Inverter, 2007, Worcester Polytechnic Institute.

Bishop, Owen, Electronics A First Course, 2006, Newnes, Oxford

Sullivan, K. R., 12 volt Lead Acid Battery Basics, 2001, http://www. Autoshop101.com 